\title{
The Quality of Four-Tier Diagnostic Test Misconception Instrument for Parabolic Motion
}

\author{
Maison ${ }^{1 *}$, Dwi Agus Kurniawan ${ }^{2}$, Retno Sari Widowati ${ }^{3}$ (iD \\ 1,2,3 Department of Physics Education, Jambi University, Jambi, Indonesia \\ *Corresponding author: maison678@gmail.com
}

\begin{abstract}
This study aims to find out how the process of developing instrument products in the form of a four-tier diagnostic test on parabolic motion material, and to find out how the quality of a four-tier diagnostic test instrument product on parabolic motion material was developed. The test subjects were all high school students of class X MIPA, taken by purposive sampling, namely 60 students in the first phase of the trial and 134 students for the 2 nd phase of the trial. of 0,3 which means valid. The instrument reliability value is 0,859 which is in the very high reliability category. This means that the developed instrument can be used to identify misconceptions. The results of expert validation indicate that the instrument is in the very good category so that it can be used to identify misconceptions. The validation results from the first validator are $85 \%$ (Good) and the second validator is $92,08 \%$ (very good). Based on the results of the study, it can be concluded that the misconception instrument developed from one-tier questions to four-tier diagnostic tests is appropriate to be used to identify students' misconceptions on parabolic motion material. This can be seen from the results of the analysis of the validity and reliability of the instrument, where all items are valid and have very high reliability.
\end{abstract}

Keywords: Development, Four-Tier, Misconception, Parabolic Motion

$\begin{array}{ll}\text { History: } & \text { Publisher: Undiksha Press } \\ \text { Received : May 08, } 2021 & \text { Licensed: This work is licensed under } \\ \text { Revised : May 10, } 2021 & \text { a Creative Commons Attribution 3.0 License } \\ \text { Accepted : June 16, } 2021 & \text { CC () O) } \\ \text { Published : July 25, } 2021 & \text { SA }\end{array}$

\section{INTRODUCTION}

Personality formation, skill and knowledge improvement are the responsibility of families, schools and communities to create a competitive, intelligent and spiritually pious generation that can be achieved through education (Rochanah, 2016; Sholichah, 2018) Education is carried out by providing examples, developing creativity, building motivation and empowering all components of educational services (Fakhriyani, 2016; Purmadi \& Surjono, 2016). One way to obtain education is through formal education, one of which is school. Teaching and learning activities in schools are able to form students' selfunderstanding both in knowledge, psychologically and socially (Hariyani, 2018; Putra, Wijayati \& Mahatmanti, 2017). Through education both in the school, family and community environment, it is hoped that the next generation will experience an increase in potential, character, intelligence and knowledge.

Physics is one of the subjects studied in formal education at school. Physics is a branch of Natural Sciences (IPA) that studies natural phenomena and also teaches various concepts that are very close to human life (Mulia, 2019; Setiawati \& Jatmiko, 2018). Physics does not only contain formulas or theories to be memorized, but physics has many concepts that must be understood in depth and able to apply them in everyday life (Hanna et al., 2016). In studying physics, students must be directed to find out and find out for themselves so as to help students understand concepts more deeply (Kurniawati \& Nita, 2018). Based on some of these opinions, the author can define physics as a science that studies natural phenomena and teaches various concepts that are closely related to everyday life.

In studying physics, understanding concepts is very important so that physics learning can become meaningful learning for students. Physics learning has a conditional nature, 
which means that a new concept is related to the previous concept (Fauziah \& Darvina, 2019; Hikmah, 2017). If students have difficulty and misunderstand a physics concept, then the student will also find it difficult to understand the next material. Misconceptions are interpreted as students' ideas from unstructured personal experiences so that they produce meanings that are not in accordance with scientific concepts (Soeharto et al., 2019). A student's understanding of a concept that contradicts scientific concepts or scientists in that field and is strongly attached to students is called a misconception (Sitepu \& Yakob, 2019; Zayyinah et al., 2018). Misconception is defined as a concept that is understood by students but is not in accordance with scientific understanding but students are confident in their understanding (Annisak et al., 2017). There are many things that cause misconceptions. The initial concept of students is very important as a cause of misconceptions because it affects the acquisition of student knowledge at the next level of education (Yuliati, 2017). There are three causes of misconceptions, namely books, teachers and the environment (Nainggolan, 2017). Meanwhile, the causes of misconceptions are preconceptions, intuition of associative and humanistic thinking, and incomplete reasoning (Adi \& Oktaviani, 2019). Based on the description above, it can be said that misconceptions are not only caused by students, but also caused by many things such as from books, teachers and the environment.

Misconceptions can hinder the process of receiving new knowledge in students. If students have experienced misconceptions at the beginning of the material, it is certain that these students will continue to experience the same mistakes until they realize that the concept they believe to be true is wrong (Kurniati, Ruslan \& Ihsan, 2018). Misconceptions in students must be a concern for teachers, this is because misconceptions can have a negative impact on student learning outcomes (Kusumaningrum, Napitulu \& Tyas, 2017; Yuliati, 2017). Many misconceptions occur in physics subjects. This is because students are often faced with concepts that are abstract, dimensions that are too small or too large, making direct observation difficult (Astiti \& Hali, 2019).

One of the physics material that is difficult to understand and many misconceptions occur is the parabolic motion material. The results of the study state that many students experience misconceptions about parabolic motion material, one of which students assume that objects with a heavier mass will take a total displacement that is closer to the launch point when compared to objects with lighter masses (Wibowo \& Sunarti, 2020). Misconceptions in the parabolic motion material must be identified immediately to improve student understanding and so as not to interfere with subsequent learning. One method that can be used to identify misconceptions is a four-level diagnostic test (Sheftyawan, Prihandono \& Lesmoro, 2018). The four-tier diagnostic test is the best test instrument at this time to measure misconceptions, because it can accurately measure the misconceptions possessed by respondents so that conclusions drawn are free from errors and lack of knowledge (Gurel, Eryilmaz \& McDermott., 2017). Instruments with four-tier format can analyze students who have misconceptions and understand concepts (Amin, Wiendartun \& Samsudin., 2016). In addition, the reason the author chose the four-tier diagnostic test is because in previous studies there was no misconception measuring instrument with a four-tier format on parabolic motion material. Based on this description, the aim of this research is to develop a four-tier misconception instrument for parabolic motion material for high school students.

\section{METHODS}

This research uses mixed methods with sequential explanatory type. The sequential explanatory method means that researchers start research using quantitative methods after completion, followed by qualitative sequentially (Mustaqim, 2016). Quantitative data were 
obtained from the four-tier diagnostic test instrument which was distributed to students. Quantitative data was collected by distributing four-tier misconceptions about parabolic motion material to students via google form. This data is then analyzed to determine the value of the validity and reliability of the instrument. While qualitative data were obtained from interviews with students, suggestions and comments on validation sheets by expert lecturers. This research was conducted at SMAN 1 Jambi City and SMAN 11 Jambi City, from March 2021 to May 2021. The population in this study were all students of class X MIPA SMAN 1 and SMAN 11 Jambi City who had studied Parabolic Motion material. The sampling technique used was purposive sampling. Purposive sampling is a method of determining non-probability samples with certain criteria for consideration (Sugiyono, 2016). In this study, the sample criteria were based on 134 students who had studied the parabolic motion material.

The first phase of the trial aims to get students' answers and reasons for the selected answers. The instrument used in this trial uses one-tier questions accompanied by open reasons. Meanwhile, the second phase of the trial aims to obtain the validity and reliability of the developed instrument. The instrument used in this trial uses a four-tier diagnostic test. The results of the first stage of the trial and the second stage of the trial will obtain quantitative data. While the qualitative data was obtained from the expert validation sheet using a Likert scale with 5 answer scales. In addition, qualitative data were also obtained through interviews with students. Interviews with students were used to find out more about the reasons students chose the answers given in the first phase of the trial.

All data obtained were analyzed by explanatory mixed-method analysis, starting with quantitative data analysis followed by qualitative data analysis. Quantitative data analysis techniques are divided into two, namely validity analysis and reliability analysis. Validity analysis was performed by looking for scatter plots, correlations between tiers, and factor analysis with the help of the SPSS program. Reliability analysis was determined by Cronbach's Alpha using the SPSS program (Syaputra, 2020). While the qualitative data analysis technique used an expert validation sheet with 5 answer scales. The five answer choices are Very Good (5), Good (4), Fair (3), Not Good (2), and Not Good (1). The procedure of this development research can be seen in Figure 1.

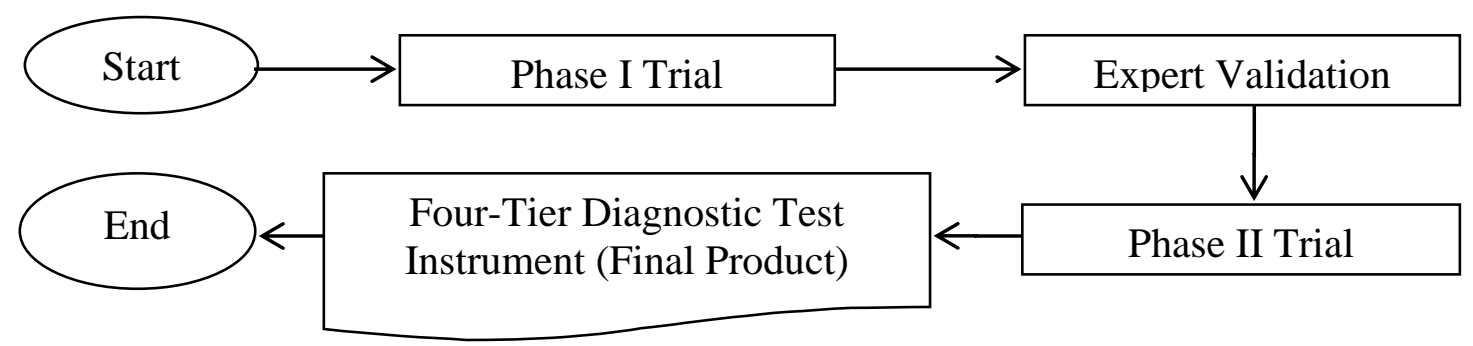

Figure 1. Research procedure

\section{RESULTS AND DISCUSSION}

\section{Results}

The type of data in this study consisted of quantitative data and qualitative data. Qualitative data were obtained through suggestions and comments from expert lecturers on the validation sheet. Quantitative data obtained through validity and reliability tests. 
Table 1. Validation Results

\begin{tabular}{clcc}
\hline Validator & \multicolumn{1}{c}{ Indicator } & Percentage & Information \\
\hline \multirow{4}{*}{$\mathbf{1}$} & Instructional aspect & $80 \%$ & Good \\
& Scope of the misconception test instrument & $80 \%$ & Good \\
& Accuracy of concepts, principles and laws & $90 \%$ & Very Good \\
& Grammar & $90 \%$ & Very Good \\
& Average percentage & $\mathbf{8 5 \%}$ & Very Good \\
& Instructional aspect & $80 \%$ & Good \\
& Scope of the misconception test instrument & $93,33 \%$ & Very Good \\
$\mathbf{2}$ & Accuracy of concepts, principles and laws & $100 \%$ & Very Good \\
& Grammar & $95 \%$ & Very Good \\
& Average percentage & $\mathbf{9 2 , 0 8 \%}$ & Very Good \\
\hline
\end{tabular}

The validation results from the first validator obtained an average percentage of $85 \%$ (Good). While the validation results from the second validator obtained an average percentage of $92.08 \%$ (Very Good).

\section{Correlation between tiers}

Table 2. Tier correlation

\begin{tabular}{|c|c|c|c|c|c|c|c|}
\hline \multicolumn{8}{|c|}{ Correlations } \\
\hline & & tier 1 & tier 2 & tier 3 & tier 4 & tier 1-3 & tier 2-4 \\
\hline \multirow[t]{2}{*}{ tier 1} & Pearson & 1 & $0.649^{* *}$ & & & & \\
\hline & Sig.(2-tailed) & & 0.000 & & & & \\
\hline \multirow[t]{2}{*}{ tier 2} & Pearson & $0.649^{* * *}$ & 1 & & & & \\
\hline & $\begin{array}{l}\text { Correlation } \\
\text { Sig.(2-tailed) }\end{array}$ & 0.000 & & & & & \\
\hline \multirow[t]{3}{*}{ tier 3} & Pearson & & & & & & \\
\hline & Correlation & & & 1 & $0.695 * *$ & & \\
\hline & Sig.(2-tailed) & & & & 0.000 & & \\
\hline \multirow[t]{2}{*}{ tier 4} & Pearson & & & $0.695 * *$ & 1 & & \\
\hline & Sig.(2-tailed) & & & 0.000 & & & \\
\hline \multirow[t]{3}{*}{ tier $1-3$} & Pearson & & & & & 1 & $0.691 * *$ \\
\hline & Correlation & & & & & & \\
\hline & Sig.(2-tailed) & & & & & & 0.000 \\
\hline \multirow[t]{3}{*}{ tier $2-4$} & Pearson & & & & & $0691 * *$ & 1 \\
\hline & Correlation & & & & & & \\
\hline & Sig.(2-tailed) & & & & & 0.000 & \\
\hline
\end{tabular}

Based on the data in Table 2, it is known that the correlation is positive, meaning that the instrument has construct validity. The correlation between tier 1 and tier 2 has a value of $0,649 * *$ with a significant value of 0,000 . This means that tier 1 and tier 2 have a strong relationship and significant data. The correlation between tier 3 and tier 4 has a value of $0,695^{* *}$ with a significant value of 0,000 . This means that tier 3 and tier 4 have a strong relationship and the data is significant. The correlation between tier 1 and tier 3 with tier 2 and tier 4 has a value of $0,691^{* *}$ with a significant value of 0,000 . This means that tier 1-3 and tier 2-4 have a strong relationship and the data is significant. 


\section{Factor Analysis}

Factor analysis led to scree plot results and construct validity results. The results of factor analysis shown in Figure 2.

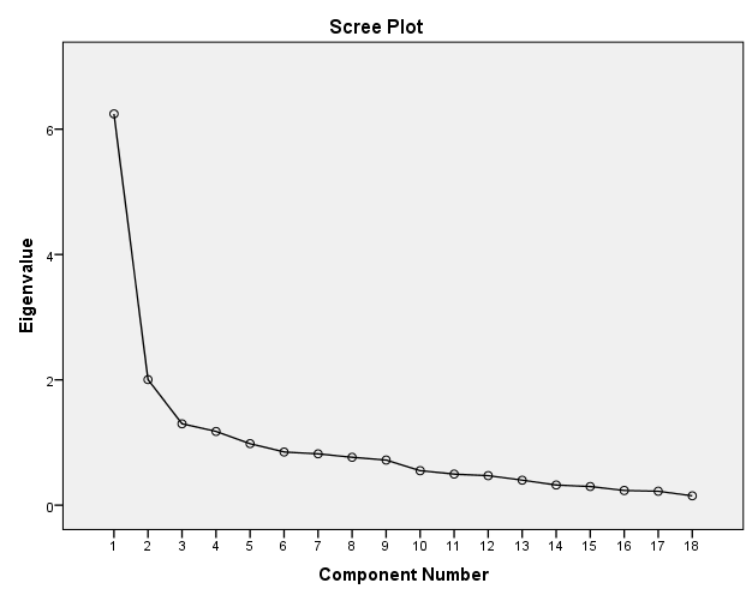

Figure 2. Sree plot test results

Based on the screenshot of the scree plot test results, it can be seen that there are 4 points that have eigenvalues $>1$, meaning that there are 4 component factors formed. The results of the construct validity of the developed instrument can be seen in the following table.

Table 3. Construct Validity

\begin{tabular}{lcccc}
\hline \multicolumn{5}{c}{ Rotated Component Matrix } \\
\hline & \multicolumn{5}{c}{ Component } & \\
\cline { 2 - 5 } & $\mathbf{2}$ & 0.642 & $\mathbf{3}$ & $\mathbf{4}$ \\
\hline item_1 & 0.380 & & 0.666 & 0.438 \\
item_2 & & 0.702 & & 0.363 \\
item_3 & 0.363 & 0.707 & \\
item_4 & & 0.758 & & \\
item_5 & & 0.728 & & \\
item_6 & & 0.408 & & \\
item_7 & & & \\
item_8 & 0.480 & 0.680 & & \\
item_9 & 0.716 & & & \\
item_10 & 0.802 & 0.314 & & \\
item_11 & 0.828 & & & \\
item_12 & & & & \\
item_13 & 0.596 & & & \\
item_14 & 0.692 & & & \\
item_15 & 0.743 & & & \\
item_16 & 0.470 & & & \\
item_17 & 0.740 & & & \\
item_18 & & & &
\end{tabular}

In Table 3 it can be seen that the item components consist of component 1, component 2 , component 3 , and component 4 . Based on the data above, all items have a validity value above 0.3 , which means that 18 items can be declared to have construct 
validity. Based on the data analysis, it is known that the reliability value is 0,859 , meaning that for a total of 18 items, the reliability is very high.

\section{Discussion}

A diagnostic test is a test that can be used to determine and ascertain the weaknesses and strengths of students in learning materials (Zaleha Samsudin \& Nugraha, 2017). In addition, diagnostic tests can also be used to identify students' misconceptions. In this study, a diagnostic test was developed in a four-tier form on the parabolic motion material. The four-tier diagnostic test is a development of the three-tier diagnostic test. (Rawh et al., 2020) said that the development is the addition of the level of student confidence in choosing answers or reasons.

Prior to testing on students, the validity test was carried out by experts. Validation was carried out by two physics lecturers. Validation by experts was carried out to assess 1) aspects of guidance, 2) scope of the misconception test instrument, 3) accuracy of concepts, principles, and laws, and 4) grammar. After validation, improvements were made according to the suggestions and comments given. Of the 20 questions that were compiled, there were 2 questions that were discarded with consideration of unclear and ambiguous questions. After the instrument is declared valid according to the expert lecturer, then the second phase of the trial is carried out to obtain the validity and reliability values. After obtaining the trial data, the data were analyzed using the SPSS program to determine the validity and reliability of the instrument. The validity of the instrument is seen by determining the relationship/correlation with the scatter plot, correlation test between tiers and factor analysis. The analysis using a scatter plot aims to determine whether the relationship between tiers has a positive correlation or a negative correlation. Based on the results of the scatter plot in Picture 2, the relationship between the tiers has a positive correlation, which means that the more students who choose the correct answer, the more students who have confidence in the answer. A positive correlation means that an increase in the first component will increase the second component (Saputra et al., 2016).

Furthermore, correlation between tiers is used to determine the relationship between tiers on one item in the form of numbers. The correlated tiers are tier 1 with tier 2 and tier 3 with tier 4, as well as tier 1 and tier 3 with tier 2 and tier 4 . In Table 2 shows that the correlation between tier 1 and tier 2, tier 3 and tier 4 correlation and correlation tier 1-3 with tier 2-4 have a positive correlation and have a strong value and the data is significant. The level of the relationship is strong if the correlation value is in the range of $0,60-0,799$ (Siregar, 2015). As for the significant data, it is because the result value is smaller than 0,05 . the data requirement is significant if the significant value is $<0,05$ (Yusri, 2016). Furthermore, the data were analyzed to find the value of construct validity. In analyzing construct validity, data interpretation is obtained through graphs with scree plots. Based on the results of the scree plot in Picture 3, there are 4 component points that have an eigenvalue $>1$, it can be interpreted that there are 4 component factors formed. Furthermore, to determine which each item belongs to which component factor, it can be seen in Table 3 by choosing the largest factor laoding value of the four component factors. The factor loading shows a large correlation between the items and the formed factors (Verdian, 2019). The greater the value of the factor loading, the closer the relationship of an item to the formed factor. Table 3 shows the Rotate Component Matrix which is used to determine the construct validity of the instrument.

If the construct validity value of each factor is positive and the magnitude is greater than 0,3, then the factor is a strong construct (Sugiyono, 2011). Based on the construct validity value, it can be seen that all items have a validity value greater than 0.3 , which means that all items have strong construct validity. If the validity value is in the range of 0,80 
- 1,00 then the item is categorized as having very high validity. If it is in the range $0,60-$ 0,80 then the item is categorized as having high validity. Meanwhile, if it is in the range 0,40 $-0,60$ then the item has sufficient validity. Based on Table 3 , it is known that items 8,11 , and 12 have very high validity. Items $1,2,3,4,5,6,9,10,13,15,16$, and 18 have high validity. While items 7,14 , and 17 have sufficient validity.

Furthermore, the reliability test was carried out with the SPSS program with Cronbach's. Alpha. The category of reliability coefficient is very high if the value of $r$ is in the range of $0,80 \mathrm{r}<1,00$. Based on the results of Cronbach's Alpha in Table 4, the results of the instrument reliability are very high, namely 0,859 . A variable or instrument is said to be reliable if it gives Cronbach's Alpha value > 0.60 (Sugiono et al., 2020). These results are declared reliable because $>0,6$. So it can be said that the instrument can be trusted to measure students' misconceptions.

Diagnostic tests in the form of four-tier can help in revealing the level of student confidence regarding how much confidence students have about the reasons for the answers they give (Maison et al., 2020). The four-tier diagnostic test instrument has advantages over other forms of tests such as the Open-ended Test, Ordinary Multiple Choice Test (MCT), Two-tier MCT, and Three-tier MCT. The four-tier diagnostic test is the best test instrument at this time to measure misconceptions, because it can accurately measure the misconceptions possessed by respondents so that conclusions drawn are free from errors and lack of knowledge. The four-tier diagnostic test instrument has the advantage that it is more specific or clearer in classifying categories of concept understanding, not understanding concepts, misconceptions and errors (Nurulwati \& Rahmadani, 2019). In addition, the level of confidence at the first and second levels was asked separately so that the analysis of the combination of answers was more specific or clearer than the three-tier diagnostic test.

The novelty in this research is that it has successfully developed a misconception instrument on parabolic motion material with a four-tier format. The instruments developed were 18 items and covered all concepts in the parabolic motion material. The concepts are the relationship of position, velocity and acceleration of parabolic motion, force on parabolic motion, velocity component on parabolic motion, object acceleration, parabolic trajectory, relationship between object reach and object travel time, velocity vector, influence of initial angle on total displacement, and parabolic motion. on an inclined plane. Thus, this instrument can be used to identify students' misconceptions about the parabolic motion material more deeply. Misconceptions will have a short-term and long-term impact on students. The short-term impact is the low understanding of students about the material being taught so that student learning outcomes are low. This is supported by the opinion which states that misconceptions greatly affect student learning outcomes (Aulia et al., 2018). The learning outcomes obtained by students vary, because the ability of students to digest a material is also different (Shalihah et al., 2016). While the long-term impact that will affect the learning process. If students experience misconceptions related to the concept of parabolic motion, then this will continue to the next learning stage.

Based on a literature study by referring to Google Scholar, the misconception instrument on parabolic motion material is only available in two-tier. In previous research, in identifying students' misconceptions on the parabolic motion material, only ordinary multiple choice tests were used with open reasons. There is no instrument of misconception of parabolic motion material with a four-level format. Therefore, the four-level format misconception instrument on the parabolic motion material is needed to measure students' misconceptions more deeply than other tests. Some of the results of misconception research on parabolic motion material are explained as follows. Research namely Development of Two-Level Multiple Choice Diagnostic Tests to Identify Misconceptions in TwoDimensional Motion Concepts (Rahayu, 2015), research namely Identification of 
Misconceptions in Parabolic Motion Materials with CRI Techniques at SMA Cilacap Regency (Amalia, 2018), research namely Analysis of Students' Misconceptions in Understanding the Materials of Straight Motion and Parabolic Motion in Class X SMAN 1 Padang (Fauziah \& Darvina, 2019). All of these studies only used multiple choice tests with open reasons.

The impact of the development of the Four-tier Diagnostic Test instrument for parabolic motion material for lecturers is that this instrument can be used as development and research in advancing science and media to identify new misconceptions in the field of science. For teachers and prospective teachers, this misconception instrument can be used to identify misconceptions that occur in students in the parabolic motion material. For prospective teachers, they can add knowledge and produce new products in research at universities. For other researchers, it can be considered for further research. There are recommendations for several parties related to the development of the four-tier diagnostic test instrument for this parabolic motion, among others, it can be developed by other researchers with different topics of physics material and it is recommended to conduct a phase I trial and phase II trial with a wider subject so as to obtain deeper results.

\section{CONCLUSION}

The developed instrument can be used to identify students' misconceptions about the parabolic motion material. The impact of the development of the Four-tier Diagnostic Test instrument for parabolic motion material for lecturers is that this instrument can be used as development and research in advancing science and media to identify new misconceptions in the field of science. For teachers and prospective teachers, this misconception instrument can be used to identify misconceptions that occur in students in the parabolic motion material. For prospective teachers, they can add knowledge and produce new products in research at universities. For other researchers, it can be considered for further research.

\section{REFERENCES}

Adi, Y. K., \& Oktaviani, N. M. (2019). Faktor-Faktor Penyebab Miskonsepsi Siswa SD pada Materi Life Processes And Livng Things. Jurnal Profesi Pendidikan Dasar, 6(1), 91104. https://doi.org/10.23917/ppd.v1i1.7988.

Amalia, R. (2018). Identifikasi Miskonsepsi Siswa Pada Materi Gerak Parabola Dengan Teknik Certainty of Response Index (CRI) Termodifikasi di SMA Kabupaten Cilacap. Universitas Islam Negeri Sunan Kalijaga.

Amin, N., Wiendartun, \& Samsudin, A. (2016). Analisis Intrumen Tes Diagnostik DynamicFluid Conceptual Change Inventory (DFCCI) Bentuk Four-Tier Test pada Beberapa SMA di Bandung Raya. Prosiding SNIPS 2016, 570-574.

Annisak, W., Astalini, \& Pathoni, H. (2017). Desain Pengemasan Tes Diagnostik Miskonsepsi Berbasis CBT (Computer Based Test). Jurnal EduFisika, 02(01), 1-12. https://doi.org/10.22437/edufisika.v2i01.3939.

Astiti, K. A., \& Hali, A. S. (2019). Pengembangan Bahan Ajar Fisika SMA Berbasis Kontekstual Materi Hukum Newton. Jurnal Fisika: Fisika Sains Dan Aplikasinya, 4(2), 108-113. https://doi.org/10.35508/fisa.v4i2.1836.

Aulia, S., Diana, N., \& Yuberti. (2018). Analisis Miskonsepsi Siswa SMP pada Materi Fisika. Indonesia Journal of Science and Mathematics Education, 01(2), 155-161. https://doi.org/10.24042/ijsme.v1i2.3516.

Fakhriyani, D. V. (2016). Pengembangan Kreativitas Anak Usia Dini. Wacana Didaktika, 4(2), 193-200. https://doi.org/10.31102/wacanadidaktika.4.2.193-200.

Fauziah, A., \& Darvina, Y. (2019). Analisis Miskonsepsi Peserta Didik Dalam Memahami 
Materi Gerak Lurus Dan Gerak Parabola Pada Kelas X SMAN 1 Padang. Pillar of Physics Education, 12(1), 73-80. http://dx.doi.org/10.24036/4813171074.

Hanna, D., Sutarto, \& Harijanto, A. (2016). Model Pembelajaran Tema Konsep Disertai Media Gambar Pada Pembelajaran Fisika Di Sma. Jurnal Pembelajaran Fisika, 5(1), 23-29. https://jurnal.unej.ac.id/index.php/JPF/article/view/3558.

Hariyani, Y. (2018). Peran Penting Psikologis terhadap Peserta Didik SD melalui Pembelajaran Tematik-Terpadu. Edureligia; Jurnal Pendidikan Agama Islam, 2(2), 70-76. https://doi.org/10.33650/edureligia.v2i2.456.

Hikmah, R. (2017). Penerapan Model Advance Organizer untuk Meningkatkan Kemampuan Pemahaman Siswa. Jurnal SAP (Susunan Artikel Pendidikan), 1(3), 271-280. https://doi.org/10.30998/sap.v1i3.1204.

Kaltakci-gurel, D., Eryilmaz, A., \& Mcdermott, L. C. (2017). Development and application of a four-tier test to assess pre-service physics teachers' misconceptions about geometrical optics. Research in Science \& Technological Education, 35(2), 238-260. https://doi.org/10.1080/02635143.2017.1310094.

Kurniati, R., Ruslan, \& Ihsan, H. (2018). Miskonsepsi Siswa Sekolah Menengah Pertama (SMP) terhadap Bilangan Bulat, Operasi dan Sifat-Sifatnya. Jurnal Ilmu Pendidikan, 1(1), 1-7. https://doi.org/10.33366/ilg.v1i1.1137.

Kurniawati, I. D., \& Nita, S. (2018). Media Pembelajaran Berbasis Multimedia Interaktif untuk Meningkatkan Pemahaman Konsep Mahasiswa. Journal of Computer and Information Technology, 1(2), 68-75. http://doi.org/10.25273/doubleclick.v1i2.1540.

Kusumaningrum, D., Napitupulu, B., \& Tyas, D. K. F. N. (2017). Analisis Miskonsepsi Siswa di Kelas XI SMA Negeri 1 Jayapura pada Materi Fungsi Komposisi. Jurnal Ilmiah Matematika Dan Pembelajarannya, 2(1), 14-21. http://ejournal.uncen.ac.id/index.php/JIMP/article/view/250.

Maison, Lestari, N., \& Widaningtyas, A. (2020). Identifikasi Miskonsepsi Siswa Pada Materi Usaha Dan Energi. Jurnal Penelitian Pendidikan IPA, 6(1), 32-39. https://doi.org/10.29303/jppipa.v6i1.314.

Mulia, S. A. (2019). PHYLAMENT (Physics Education and Experiment). Jurnal Bina Desa, $1(1)$, $12-15$. https://journal.unnes.ac.id/nju/index.php/jurnalbinadesa/article/view/19642.

Mustaqim. (2016). Metode Penelitian Gabungan Kuantitatif Kualitatif/Mixed Methods Suatu Pendekatan Alternatif. Jurnal Intelegensia, 04(1), 1-9. https://doi.org/10.34001/intelegensia.v6i1.1351.

Nainggolan, L. (2017). Identification of Factors Causes Student's Misconception on Human Circulatory System Topic in Grade IX SMP Nurul Fadhilah Medan. Prosiding Seminar Nasional III Biologi Dan Pembelajarannya, September, 530-537.

Nurulwati, \& Rahmadani, A. (2019). Perbandingan Hasil Diagnostik Miskonsepsi menggunakan Three Tier dan Four-Tier Diagnostic Test pada Materi Gerak Lurus. Jurnal Pendidikan Sains Indonesia, 7(2), 101-111. https://doi.org/10.24815/jpsi.v7i2.14436.

Nurulwati, Veloo, A., \& Ali, R. M. (2014). Suatu Tinjauan Tentang Jenis-Jenis Dan Penyebab Miskonsepsi Fisika. Jurnal Pendidikan Sains Indonesia, 2(1), 87-95. http://e-repository.unsyiah.ac.id/JPSI/article/view/7636.

Purmadi, A., \& Surjono, H. D. (2016). Pengembangan Bahan Ajar Berbasis Web Berdasarkan Gaya Belajar Siswa Untuk Mata Pelajaran Fisika. Jurnal Inovasi Teknologi Pendidikan, 3(2), 151-165. https://doi.org/10.21831/jitp.v3i2.8285.

Putra, R. S., Wijayati, N., \& Mahatmanti, F. W. (2017). Pengaruh Penggunaan Media Pembelajaran Berbasis Aplikasi Android Terhadap Hasil Belajar Siswa. Jurnal Inovasi Pendidikan Kimia, 11(2), 2009-2018. 
https://journal.unnes.ac.id/nju/index.php/JIPK/article/view/10628.

Rahayu, S. (2015). Pengembangan Tes Diagnostik Pilihan Ganda Dua Tingkat untuk Mengidentifikasi Miskonsepsi pada Konsep Gerak Dua Dimensi. UIN Syarif Hidayatullah.

Rawh, P., Samsudin, A., \& Nugraha, M. G. (2020). Pengembangan Four-Tier Diagnostic Test untuk Mengidentifikasi Profil Konsepsi Siswa pada Materi Alat-Alat Optik. WaPFi (Wahana Pendidikan Fisika), 54), https://doi.org/10.17509/wapfi.v5i1.22888.

Rochanah. (2016). Peranan Keluarga, Sekolah dan Masyarakat dalam Menunjang Pembelajaran yang Efektif. ELEMENTARY: Islamic Teacher Journal, 4(1). https://doi.org/10.21043/elementary.v4i1.1981.

Saputra, T. E., Barmawi, M., Ermawati, \& Sa'diyah, N. (2016). Korelasi Dan Analisis Lintas Komponen Komponen Hasil Kedelai Famili F6 Hasil Persilangan Wilis X B3570. Jurnal Penelitian Pertanian Terapan, 16(1), 54-60. https://doi.org/10.25181/jppt.v16i1.76.

Setiawati, W. E., \& Jatmiko, B. (2018). Penerapan Model Pembelajaran Inkuiri Terbimbing untuk Meningkatkan Pemahaman Konsep Fisika Siswa SMA. Inovasi Pendidikan Fisika, 07(02), 287-291. https://jurnal.unesa.ac.id/index.php/inovasi-pendidikanfisika/article/view/24235.

Shalihah, A., Mulhayayiah, D., \& Alatas, F. (2016). Identifikasi Miskonsepsi Menggunakan Tes Diagnostik Three-Tier pada Hukum Newton dan Penerapannya. JoTaLP: Journal of Teaching and Learning Physics, 1(1), 24-33. https://doi.org/10.15575/jotalp.v1i1.3438.

Sheftyawan, W. B., Prihandono, T., \& Lesmono, A. D. (2018). Identifikasi Miskonsepsi Siswa Menggunakan Four-tier Diagnostic Test pada Materi Optik Geometri. Jurnal Pembelajaran Fisika, 7(2), 147-153. https://jurnal.unej.ac.id/index.php/JPF/article/download/7921/5577.

Sholichah, A. S. (2018). Teori-Teori Pendidikan dalam Al-Qur'an. Edukasi Islami: Jurnal Pendidikan Islam, 7(01), 23-46. https://doi.org/10.30868/ei.v7i01.209.

Siregar, S. (2015). Statistik Parametrik Untuk Penelitian Kuantitatif (F. Hutari (ed.)). PT Bumi Aksara.

Sitepu, E. B., \& Yakob, M. (2019). Analisis Miskonsepsi Siswa pada Materi Hukum Newton di Kelas X IPA SMA Negeri 1 Berastagi. GRAVITASI Jurnal Pendidikan Fisika Dan Sains, 2(2), 23-29. https://ejurnalunsam.id/index.php/JPFS/article/view/1708.

Soeharto, Csapó, B., Sarimanah, E., Dewi, F. I., \& Sabri, T. (2019). A Review of Students' Common Misconceptions in Science and Their Diagnostic Assessment Tools. Jurnal Pendidikan IPA Indonesia, 8(2), 247-266. https://doi.org/10.15294/jpii.v8i2.18649.

Sugiono, Noerdjanah, \& Wahyu, A. (2020). Uji Validitas dan Reliabilitas Alat Ukur SG Posture Evaluation. Jurnal Keterapian Fisik, 5(1), 55-61. https://doi.org/10.37341/jkf.v5i1.167.

Sugiyono. (2011). Metode Penelitian Kuantitatif, Kualitatif, dan R\&D. Alfabeta.

Suparno, P. (2013). Miskonsepsi Perubahan Konsep Dalam Pendidikan Fisika. PT Grasindo.

Syaputra, D. (2020). Pengaruh Harga dalam Meningkatkan Volume Penjualan pada Standard Minimarket Jagakarsa di Jakarta Selatan. Jurnal Manajemen Kompeten, 3(1), 26-38. http://jurnal.stier.ac.id/index.php/mnjm/article/view/141.

Verdian, E. (2019). Analisis Faktor yang merupakan Intensi Perpindahan Merek Transportasi $\begin{array}{llll}\text { Online } & \text { Si }\end{array}$ http://publication.petra.ac.id/index.php/manajemen-bisnis/article/view/8176.

Wibowo, C., \& Sunarti, T. (2020). Analisis dan Prediksi Miskonsepsi Siswa Pada Materi Gerak Parabola. IPF: Inovasi Pendidikan Fisika, 09(02), 257-264. 
https://jurnal.unesa.ac.id/index.php/inovasi-pendidikan-fisika/article/view/34768.

Yuliati, Y. (2017). Miskonsepsi Siswa pada Pembelajaran IPA serta Remediasinya. Jurnal Bio Educatio, 2, 50-58. https://core.ac.uk/download/pdf/228883658.pdf.

Yusri. (2016). Ilmu Pragmatik dalam Perspektif Kesopanan Berbahasa. Deepublish.

Zaleha, Samsudin, A., \& Nugraha, M. G. (2017). Pengembangan Instrumen Tes Diagnostik VCCI Bentuk Four-Tier Test pada Konsep Getaran. Jurnal Pendidikan Fisika Dan Keilmuan (JPFK), 3(1), 36-42. https://doi.org/10.25273/jpfk.v3i1.980.

Zayyinah, Munawaroh, F., \& Rosidi, I. (2018). Identifikasi Miskonsepsi Siswa SMP dengan Certainty of Response Index (CRI) pada Konsep Suhu dan Kalor. Science Education National Conference, 78-89. https://ecoentrepreneur.trunojoyo.ac.id/nser/article/view/4795. 